\title{
Relationship of initial class attendance and seating location to academic performance in psychology classes
}

\author{
L. W. BUCKALEW and J. D. DALY \\ Alabama A \& M University, Normal, Alabama \\ and \\ K. E. COFFIELD \\ University of Alabama in Huntsville, Huntsville, Alabama
}

\begin{abstract}
Needs for accountability and cost effectiveness in educational programs were noted, with particular concern for academic performance. Emphasizing the influence of instructor and student expectations, individual and behavioral variables that contribute to assumptions about performance are reviewed. In this study, we evaluated relationships to academic performance of classroom seating location and initial class attendance in psychology classes involving over 200 students at two universities. Based on point-biserial correlations, seating position was unrelated to performance, whereas initial attendance was strongly related. Findings were interpreted in terms of possible instructor or student biases, and several additional variables were suggested for expanded research.
\end{abstract}

In an era of increasing concern for educational accountability and cost effectiveness, research is being focused on variables that may relate to educational outcome. These concerns are certainly relevant to higher education (B. F. Skinner, 1984), inclusive of psychology courses (Buckalew \& Lewis, 1982). Academic performance and demonstrable competence loom as bottom-line considerations, and all variables of potential impact are important. Perhaps one of the most important psychological variables is expectation, long established as consequential to performance in both instructor/researcher and student/subject (Orne, 1962; Rosenthal \& Fode, 1963; Rosenthal \& Jacobson, 1968). The present study investigated the validity of traditional assumptions or expectations based on relating class attendance and classroom seating location with academic performance. Such assumptions can produce biases that may either detract from or artificially inflate instructional outcomes.

Several stereotyped instructor/student assumptions relating student characteristics and behaviors to performance have gained recent research attention. Some support is noted for the superiority of women in science and mathematics (Deboer, 1984; Lecompte, Kaufman, Rousseeuw, \& Tassin, 1983), and women may be advantaged on class-rank performance and instructor ratings of writ-

This research was, in part, supported through the Summer Institute on Research program. The Graduate School. Alabama A \& M University. Address reprint requests to L. W. Buckalew, Army Research Institute, Fort Hood, TX 76544. ten performance (Bernard, 1979; Thomas, Alexander, \& Eckland, 1977). An attitudinal variable of recent attention is student apathy, with no sex, race, or era differences found, although some suggestion of academicclassification differences has been indicated (Coffield, 1981; Coffield \& Buckalew, 1985). Class size, as related to academic performance, has been well researched, although reviews suggest inconclusive findings (Albritton, 1984; Cuttance, 1980). There is some evidence to indicate assignment of higher evaluations and student preference for small classes (Dickson, 1984; McConnell \& Sosin, 1984), and other studies tend to support the efficacy of small classes (South Carolina State Department of Education, 1980). Class meeting time was found to be related to performance, with students in earlier classes obtaining lower grades (N. F. Skinner, 1985). Strong relationships between attendance and performance were indicated by Polachek, Kniesner, and Harwood (1978) and by Vidler (1980); however, only overall attendance, as opposed to initial attendance upon which instructors might base early opinions about students, was considered. Millard and Stimpson (1980) found classroom seating location unrelated to performance, although student satisfaction was closely related to proximity to the instructor.

\section{METHOD}

Subjects

Nine psychology classes having a total of 215 undergraduate students at two universities were studied. The courses included were general (4), physiological, educational, and experimental psychology, and behavioral statistics (2). Students were not informed of the research interest. 


\section{Materials}

Standard grade-report forms, initial attendance rosters, and classroom seating charts provided for data collection and recording.

\section{Procedure}

At the first scheduled meeting of each class, an attendance sheet was signed by students for later comparison to final official class rosters to allow a dichotomy of initial versus later attendees. In the last 2 weeks of each of six classes, seating charts were constructed and a front- versus back-half dichotomy was applied. Level of academic performance was taken from final grade-report forms for each class. Data of students who withdrew from a class or received an "Incomplete" were excluded from analysis.

\section{RESULTS}

The dependent variable, academic performance, was assumed continuous, with grades ranging from " $A$ " (4) to " $F$ " ( $(0)$. Antecedent variables, both dichotomous, were coded " 1 " for initial attendance or front seating or " 0 ", for initial absence or rear seating. Point-biserial correlation coefficients were obtained for resulting data. The $r_{\mathrm{pbi}}$ for seating location and performance was .147 $[t(107)=$ $1.54, p>.05]$. Grade means for students in the front (55\%) and back were 2.40 and 2.06 , respectively. Initial attendance related to performance as an $r_{\mathrm{pbi}}$ of $.309[t(187)$ $=4.44, p<.01]$. Grade means for initial attendees (49\%) and absentees were 2.39 and 1.63 , respectively.

\section{DISCUSSION}

Exploratory findings suggest two conclusions, both guarded due to the limited data base. The correlation of classroom seating location and academic performance, in agreement with Millard and Stimpson (1980), showed no meaningful relationship. An assumption or expectation of performance based on this variable appears to lack empirical validity and must be viewed as biasing. Findings of Polachek et al. (1978) and Vidler (1980), reflecting a strong positive relationship between attendance and student performance, were supported, even when considering only initial class attendance. This variable appears to be a strong index of later academic performance in psychology classes, and, in all probability, has underpinnings of conscientiousness, integrity, and motivation.

Given the importance of instructor and student assumptions or ex pectations to academic performance, several interesting opportunities, if not needs, are suggested. A cross-discipline survey of college educators and students seems warranted to determine the nature and extent of assumptions about performance based on student characteristics, behaviors, and classroom conditions. With identification of typical and, particularly, mutually held assumptions, research efforts could be devoted to appraising their validity. Ultimately, there needs to be an educational effort to dispel erroneous assumptions and determine the substrates for those confirmed. In sum, we propose a whole new research effort aimed toward the eventual better education of students.

\section{REFERENCES}

Albritton, T. (1984). A review of recent literature on the effects of class size, with implications for English and language arts instruction. Resources in Education, Document No. Ed 248517.

BERNARD, M. F. (1979). Does sex role behavior influence the way teachers evaluate students? Journal of Educational Psychology, 71, 553-562.

Buckalew, L. W., \& Lewis, H. H. (1982). Curriculum needs: Life preparation for undergraduate psychology majors. Psychological Reports, 51, 77-78.

CofFIELD, K. E. (1981). Student apathy: A comparative study. Teaching of Psychology, 8, 26-28.

Coffield, K. E., \& BUCKalew, L. W. (1985). University student apathy: Sex, race, and academic class variables. Psychological Record, 35, 459-463.

CutTance, P. (1980). Do schools consistently influence the performance of their students? Educational Review, 32, 267-280.

Deboer, G. E. (1984). A study of gender effects in the science and mathematics course-taking behavior of a group of students who graduated from college in the late 1970s. Journal of Research in Science Teaching, 21, 95-103.

Dickson, V. A. (1984). An economic model of faculty grading practices. Journal of Economic Education, 15, 197-203.

Lecompte, D., Kaufman, L., Rousseeuw, P., \& Tassin, A. (1983). Search for the relationship between academic performance and some psychosocial factors: The use of a structured interview. Acta Psychiatrica Belgica, 83, 598-608.

McConnell, C. R., \& Sosin, K. (1984). Some determinants of student attitudes toward large classes. Journal of Economic Education, 15, 181-190.

Millard, R. J., \& Stimpson, D. V. (1980). Enjoyment and productivity as a function of classroom seating location. Perceptual \& Motor Skills, 50, 439-444.

ORNE, M. T. (1962). On the social psychology of the psychology experiment: With particular reference to demand characteristics and their implications. American Psychologist, 17, 776-783.

PolacheK, S. W., KNiesner, T. J., \& Harwood, H. J. (1978). Educational production functions. Journal of Educational Statistics, 3, 209-231.

Rosenthal, R., \& Fode, K. L. (1963). Psychology of the scientist: V. Three experiments in experimenter bias. Psychological Reports, 12, 491-511.

Rosenthal, R., \& JACOBSON, L. (1968). Pygmalion in the classroom: Teacher expectation and pupils' intellectual development. New York: Holt, Rinehart, \& Winston.

Skinner, B. F. (1984). The shame of American education. American Psychologist, 39, 947-954.

SKINNER, N. F. (1985). University grades and time of day of instruction. Bulletin of the Psychonomic Society, 23, 67.

South Carolina State Department of Education (1980). The effects of class size on student achievement. A review of the literature. (ERIC Document Reproduction Service No. ED 202 136). Columbia, SC: Author.

Thomas, G. E., Alexander, K. I., \& Eckland, B. K. (1977). Access to higher education: How important are race, sex, social class and academic credentials for college access? Center for Social Organization of Schools Report, 226, 22 pp.

VIDLER, D. C. (1980). Curiosity, academic performance, and class attendance. Psychological Reports, 47, 589-590. 